\title{
PENGEMBANGAN MEDIA PEMBELAJARAN IPA TERPADU BERBASIS KOMPUTER TEMA BUNYI MELALUI LESSON STUDY DI SMP
}

\author{
Sri Nartuti \\ Guru SMP Negeri 3 Ketapang \\ Email : srinartuti1966@gmail.com
}

\begin{abstract}
Abstrak
Berdasarkan hasil observasi dan wawancara guru di SMP Negeri 3 Ketapang, bahwa pembelajaran di sekolah mulai merintis untuk menggunakan pembelajaran terpadu. Kegiatan lesson study dilakukan agar pembelajaran menjadi baik. Tujuan dilakukan penelitian ini adalah untuk mengetahui kelayakan media pembelajaran IPA terpadu yang dikembangkan. Penelitian ini menggunakan metode Research and Development $(R \& \& \quad D)$. Uji coba menggunakan media pembelajaran dilaksanakan di SMP Negeri 3 Ketapang. Data yang diambil adalah data penilaian oleh pakar media dan pakar materi, tanggapan guru, tanggapan peserta didik serta hasil belajar peserta didik. Hasil penelitian menunjukkan bahwa rata-rata penilaian pakar media sebesar 2,83 dengan kriteria "sangat baik", rata-rata penilaian pakar materi sebesar 2,66 dengan kriteria "baik" dan penilaian keterpaduan semua aspek mendapat jawaban "ya" yang menunjukkan media pembelajaran dinyatakan layak. Keberterimaan media pembelajaran oleh peserta didik pada uji coba skala terbatas memperoleh kriteria "baik dan sangat baik" sebesar 93\% dan pada uji coba skala luas memperoleh kriteria "baik dan sangat baik" sebesar 100\%. Keberterimaan media pembelajaran oleh guru sebesar 3,19 dengan kriteria "baik". Kegiatan lesson study yang dilakukan oleh tim ahli memperoleh skor rata-rata pada pertemuan 1 sebesar 73,6\% mengalami peningkatan pada pertemuan 2 sebesar $83,9 \%$. Hasil evaluasi peserta didik dengan menggunakan media pembelajaran IPA terpadu menunjukkan ketuntasan klasikal sebesar $88,89 \%$ dengan nilai $\geq 75$. Berdasarkan hasil penelitian di atas, dapat disimpulkan bahwa media pembelajaran layak digunakan sebagai media pembelajaran IPA terpadu pada tema bunyi.
\end{abstract}

\section{Kata Kunci : IPA terpadu, lesson Study, Media Pembelajaran, Tema Bunyi}

\section{PENDAHULUAN}

Pembelajaran terpadu merupakan pendekatan pembelajaran yang melibatkan beberapa mata pelajaran untuk memberikan pengalaman yang bermakna kepada peserta didik. Dikatakan bermakna karena dalam pembelajaran terpadu, peserta didik akan memahami konsep-konsep yang mereka pelajari melalui pengamatan langsung dan menghubungkannya dengan konsep lain yang sudah mereka pahami (Hernawan, 2008: 1.5). Pembelajaran terpadu akan membantu menciptakan kesempatan yang luas bagi peserta didik untuk melihat dan membangun konsep- konsep yang saling berkaitan. Dengan demikian, pembelajaran terpadu memberikan kesempatan kepada peserta didik untuk memahami masalah yang kompleks yang ada di lingkungan sekitarnya dengan pandangan yang utuh. Ciri pembelajaran terpadu menggunakan tema untuk mengkaitkan beberapa mata pelajaran sehingga dapat memberikan pengalaman kepada peserta didik. Pembelajaran terpadu lebih menekankan pada keterlibatan peserta didik dalam proses belajar secara aktif dalam proses pembelajaran, sehingga peserta didik dapat memperoleh pengalaman langsung dan terlatih untuk dapat menemukan sendiri berbagai pengetahuan yang dipelajarinya. Melalui pengalaman langsung peserta didik dapat memahami konsep-konsep yang mereka pelajari dan menghubungkan dengan konsep lain yang telah dipahaminya.

Berkaitan dengan pengembangan pembelajaran IPA terpadu tersebut, masalah yang terjadi di lapangan saat ini adalah banyak guru IPA yang belum menerapkan IPA terpadu dalam kegiatan pembelajaran. Hal tersebut dikarenakan adanya berbagai kendala antara lain, guru-guru yang tersedia merupakan guru bidang studi IPA tertentu sehingga sulit untuk beradaptasi dan melakukan penggabungan terhadap berbagai bidang studi tersebut, belum adanya bahan ajar atau media pembelajaran yang dapat digunakan oleh guru untuk membantu dalam menyampaikan materi pelajaran sehingga pencapaian Standar Kompetensi dan Kompetensi Dasar tidak akan tercapai (Trianto, 2007: 98).

Tema bunyi adalah materi yang mempelajari konsep-konsep abstrak, karena proses bunyi dapat terdengar oleh telinga tidak dapat dilihat oleh mata secara langsung. Kegiatan pembelajaran tema bunyi terbatas pada penjelasan konsep dan hanya bisa melihat gambar saja, padahal konsep yang abstrak dapat dengan mudah dipahami peserta didik apabila melihat video atau dengan adanya pengalaman konkret.

Berawal dari masalah peserta didik yang sulit untuk menerima ilmu pengetahuan tentang bunyi, pengembangan ilmu pengetahuan teknologi informasi dan komunikasi, tuntutan KTSP serta obyek pada materi bunyi yang abstrak maka perlu dikembangkan media pembelajaran berbasis komputer sebagai salah satu solusi atau alat bantu untuk mensimulasikan kegiatan pembelajaran di kelas. Animasi gambar sebagai salah satu produk inovasi media pembelajaran berbasis komputer dan teknologi dapat diterapkan di sekolah yang telah menerapkan teknologi informasi (IT) dalam proses pembelajarannya. Penggunaan animasi gambar sangat membantu sekolah dalam penyampaian materi bunyi yang merupakan materi abstrak yang sangat sulit dipahami peserta didik.

SMP Negeri 3 Ketapang merupakan sekolah yang sangat maju berakreditasi A, Sekolah tersebut 
mempunyai peserta didik yang sangat berkualitas tapia da juga siswa yang kurang dalam menerima materi yang diberikan oleh guru. Adanya kelemahan tersebut, maka dilakukan kegiatan lesson study. Kegiatan lesson study bertujuan untuk menjadikan pembelajaran lebih baik, karena dalam kegiatan lesson study terjadi dalam tiga tahapan yang selanjutnya berbentuk siklus yang saling berhubungan.

Pembelajaran ini bukanlah suatu stategi atau metode dalam pembelajaran, tetapi merupakan salah satu upaya pembinaan untuk meningkatkan proses pembelajaran yang dilakukan oleh sekelompok guru secara kolaboratif dan berkesinambungan, dalam merencanakan, melaksanakan, mengobservasi dan melaporkan hasil pembelajaran. Keunggulannya adalah guru lain dapat pula memberikan pandangan-pandangan guna memberikan solusi tentang kendalakendala yang dihadapi peserta didik dan dapat diberikan masukan oleh observer sehingga media yang dikembangkan lebih efektif.

Manfaat dari lesson study untuk guru adalah untuk mengidentifikasi masalah. Pendekatan ini dapat dijadikan salah satu alternatif solusi guna mendorong perubahan pembelajaran di kelas menjadi lebih efektif. Pembelajaran ini merupakan kegiatan memperbaiki proses dan hasil pembelajaran peserta didik secara terus menerus dan dapat mendorong terbentuknya sebuah komunitas belajar untuk melakukan perbaikan diri, pada tataran individual maupun manajerial.

Berdasarkan latar belakang di atas, maka diperlukan pengembangan animasi gambar sebagai media pembelajaran berbasis komputer pada tema bunyi dan pemanfaatan media yang di kembangkan akan diterapkan dan dikaji melalui lesson study agar proses pembelajaran menjadi lebih menarik dan efektif bagi Peserta didik.

Model pembelajaran adalah suatu perencanaan atau suatu pola yang digunakan sebagai pedoman dalam merencanakan pembelajaran di kelas atau pembelajaran dalam tutorial. Model pembelajaran mengacu pada pendekatan pembelajaran yang akan digunakan, termasuk didalamnya tujuan-tujuan pengajaran, tahap- tahap dalam kegiatan pembelajaran, lingkungan pembelajaran,dan pengelolaan kelas (Arends, 1997).

Menurut Trianto (2007: 41), model pembelajaran terpadu dapat dikelompokkan menjadi tiga klasifikasi pengintegrasian kurikulum, yaitu: 1) pengintegrasian di dalam satu disiplin ilmu, misalnya di bidang IPA dengan memadukan dua tema dalam fisika dan biologi, atau kimia dan biologi yang mempunyai relevansi menjadi sebuah tema baru, 2) pengintegrasian beberapa disiplin ilmu, misalnya memadukan tema yang ada dalam bidang ilmu sosial dengan tema yang ada dalam bidang alam yang mempunyai relevansi menjadi sebuah tema baru, 3) pengintegrasian di dalam dan beberapa disiplin ilmu, oleh karena itu, model ini merupakan model pembelajaran terpadu yang paling kompleks karena mentautkan antara disiplin ilmu yang serumpun sekaligus bidang ilmu yang berbeda.

Media pembelajaran IPA terpadu adalah segala sesuatu yang dapat menyalurkan pesan, dapat merangsang fikiran, perasaan, dan kemauan peserta didik sehingga dapat mendorong tercapainya proses belajar pada diri peserta didik.
Media pembelajaran merupakan salah satu komponen pembelajaran yang berkaitan dengan komponen lainnya dalam pembelajaran dalam rangka membantu peserta didik belajar. Tanpa media pembelajaran yang bervariasi maka kegiatan inti pembelajaran terpadu tidak akan berjalan dengan efektif.

Dengan menggunakan media pembelajaran, kita dapat memanfaatkan nilai yang terkandung dalam media pembelajaran untuk memfasilitasi terjadinya proses belajar pada diri peserta didik. Berikut ini beberapa nilai yang dapat dipetik dari penggunaan media dalam pembelajaran terpadu a) media dapat mengkongkretkan konsep- konsep yang abstrak. konsep-konsep yang dirasakan masih bersifat abstrak dan sulit dijelaskan secara langsung kepada peserta didik disederhanakan melalui pemanfaatan media pembelajaran, b) media pembelajaran dapat menghadirkan objek-objek yang terlalu berbahaya atau sukar didapat ke dalam lingkungan belajar, c) media dapat menampilkan objek yang terlalu besar atau terlalu kecil, d) media dapat memperlihatkan gerakan yang terlalu cepat, dengan menggunakan media film (slow motion) (Hernawan, 2008: 2.24).

Dengan memperhatikan nilai dan kekuatan yang dimiliki media pembelajaran dalam mengoptimalkan pembelajaran, penggunaan media pembelajaran memberikan kontribusi yang sangat besar terhadap tercapainya kompetensi dasar yang harus dikuasai peserta didik. Pemanfaatan media dalam kegiatan pembelajaran terpadu adalah penggunaan media pembelajaran. Dengan media pembelajaran kita dapat mensimulasikan dengan pembuatan benda tiruan untuk membantu peserta didik dalam pembelajran. Benda tiruan yang dimaksud berupa media berbasis komputer yang memuat tiruan simulasi praktikum pokok bahasan tertentu yang sulit dilakukan melalui pengalaman langsung atau konstruksi-konstruksi yang abstrak, sehingga peserta didik dapat memperoleh pengalaman yang konkrit (Santyasa 2007).

Aspek dan kriteria penilaian media pembelajaran dimodifikasi menjadi tiga aspek, yaitu aspek rekayasa perangkat lunak, aspek instructional design (desain pembelajaran) dan aspek komunikasi visual (Wahono, 2006). Kelayakan media ditinjau dari aspek rekayasa perangkat lunak meliputi (a) efektif dan efisien dalam pengembangan maupun penggunaan media pembelajaran, (b) maintainable artinya dapat dipelihara/dikelola dengan mudah, (c) usabilitas yaitu mudah digunakan dan sederhana dalam pengoperasiannya, (d) kompatibilitas yaitu media pembelajaran dapat diinstalasi/dijalankan di berbagai hardware dan software yang ada dan (e) reusable yaitu sebagian atau seluruh program media pembelajaran dapat dimanfaatkan kembali untuk mengembangkan media pembelajaran lain.

Aspek yang kedua yaitu aspek desain pembelajaran meliputi (a) kejelasan tujuan pembelajaran, (b) relevansi tujuan pembelajaran dengan SK/KD/ Kurikulum, (c) kesesuaian materi dengan tujuan pembelajaran, (d) ketepatan penggunaan strategi pembelajaran, (e) interaktivitas, (f) pemberian motivasi belajar, (g) kontekstualitas dan aktualitas, (h) kedalaman materi, (i) kemudahan untuk dipahami, (j) sistematis/runtut/alur logika jelas, (k) kejelasan uraian, pembahasan, contoh, simulasi dan latihan, dan (1) konsistensi evaluasi dengan tujuan 
pembelajaran(Wahono, 2006).

Aspek terakhir yaitu aspek komunikasi visual meliputi (a) komunikatif (sesuai sasaran dan dapat diterima dengan keinginan sasaran), (b) kreatif dalam Zide dan penuangan gagasan, (c) sederhana dan memikat, (d) audio (narasi, sound effect, backsound, musik), (e) visual (layout design, typography, warna), (f) media bergerak (animasi), dan ( $\mathrm{g}$ ) layout nteractive (ikon navigasi), (Wahono, 2006).

Lesson study adalah pengkajian terhadap pembelajaran, yang merupakan kegiatan yang diawali dengan pengembangan perencanaan secara bersama, proses pembelajaran terbuka dengan melibatkan sejumlah observer dan refleksi atau diskusi pasca pembelajaran, merupakan suatu kegiatan yang sangat potensial untuk menciptakan proses interaksi antar berbagai pihak yaitu guru dan para pakar dari pembelajaran. Interaksi akan dapat terjadi dalam berbagai tahapan kegiatan, maka sangat dimungkinkan terjadinya sharing pengetahuan serta tacit knowledge yang diperoleh melalui pengamatan terhadap pembelajaran (Parmin, 2013: 72)

Kegiatan lesson study dapat mendatangkan banyak manfaat yaitu meliputi meningkatnya pengetahuan guru tentang materi ajar dan pembelajarannya, meningkatnya pengetahuan guru tentang cara mengobservasi aktivitas belajar peserta didik, menguatnya hubungan kolegalitas baik antar guru maupun dengan observer selain guru, menguatnya hubungan antara pelaksanaan pembelajaran sehari-hari dengan tujuan pembelajaran jangka panjang, meningkatnya motivasi guru untuk senantiasa berkembang, dan meningkatnya kualitas rencana pembelajaran (termasuk komponen-komponennya seperti bahan ajar, teaching materials (hands on), dan strategi pembelajaran) (Parmin, 2013: 76).

Menurut Atip 2010, dalam penelitiannya menyatakan ada perbedaan kemampuan pengajar dalam mengembangkan pembelajaran IPA terpadu melalui lesson study tidak hanya bermanfaat bagi peserta didik untuk meningkatkan hasil belajar, tetapi juga memberi pengalaman langsung tentang bagaimana mengelola pembelajaran yang bermakna. Pembelajaran bermakna berarti apa yang dipelajari ada dalam keseharian dan bermanfaat dalam keseharian peserta didik. Menurut teori Ausubel tentang belajar bermakna, menyatakan bahwa belajar dapat dilakukan dengan menghubungkan pengetahuan yang diperoleh dengan apa yang sudah dimiliki. Ausubel juga menyatakan bahwa belajar dapat diklasifikasikan ke dalam dua dimensi. Dimensi pertama berhubungan dengan cara informasi atau materi pelajaran disajikan pada peserta didik melalui penerimaan atau penemuan. Dimensi kedua menyangkut cara bagaimana peserta didik dapat mengaitkan informasi itu pada struktur kognitif yang telah ada. Struktur kognitif ialah fakta fakta, konsep-konsep dan generalisasi yang telah dipelajari dan diingat oleh peserta didik.

Pembelajaran dengan komputer akan memberikan motivasi yang lebih tinggi karena komputer selalu dikaitkan dengan kesenangan, permainan dan kreativitas, sehingga pembelajaran itu akan meningkat. Komputer sebagai media pembelajaran yang baik di sekolah, harus memenuhi beberapa syarat. Sebab suatu media pembelajaran mempunyai kemampuan untuk meningkatkan motivasi belajar peserta didik. Penggunaan komputer sebagai media pembelajaran harus mempunyai tujuan untuk memberikan motivasi kepada peserta didik. Selain itu, harus mampu merangsang peserta didik untuk mengingat apa yang sudah dipelajari dan dapat memberikan rangsangan belajar baru bagi peserta didik.

Tema Bunyi dipadukan antar berbagai disiplin ilmu. Dalam hal ini adalah Fisika dan Biologi. Dilihat dari disiplin ilmu fisika terdapat materi pengertian bunyi, cepat rambat bunyi, jenis-jenis bunyi berdasarkan frekuensi, karakteristik bunyi, resonansi dan pemantulan bunyi, materi itu terdapat pada kelas VIII semester genap dan dipadukan dengan disiplin ilmu biologi yang terdapat materi telinga, yaitu membahas tentang bunyi dapat terdengar oleh telinga. Tema yang akan dikembangkan hanya materi yang dapat disimulasikan menggunakan animasi yaitu bunyi masuk ke telinga sehingga bunyi dapat terdengar.

Materi bunyi merupakan suatu materi yang menjelaskan tentang bagaimana bunyi dihasilkan. Pada tema ini, penulis akan menjelaskan tentang materi bunyi. Dimana pada tema ini penulis akan menjelaskan tentang mekanisme mendengar, menjelaskan konsep cepat rambat bunyi, membedakan bunyi berdasarkan frekuensinya, menjelaskan karakteristik bunyi, menunjukkan gejala resonansi dalam kehidupan sehari-hari dan menjelaskan konsep pemantulan bunyi.

\section{METODE PENELITIAN}

Metode penelitian merupakan salah satu factor yang sangat penting dalam pelaksanaan penelitian. Berhasil tidaknya penelitian banyak tergantung pada tepatnya dalam memilih serta penerapan metode penelitian, sehingga dapat diperoleh penelitian yang dapat dipertanggung jawabkan.

Jenis penelitian ini merupakan penelitian Tindakan (action reserch) dengan tahapan sebagai berikut : (1) Penelitian ini dimulai dari pelaksanaan workshop lesson study, yaitu pembentukan tim lesson study dan penyamaan persepsi pelaksanaan antar anggota tim; (2) Tahap pelaksanaan lesson study Plan, tahap ini, tim lesson study secara bersama-sama melakukan penelitian awal dan mengumpulkan informasi tentang pelaksanaan pembelajaran IPA di SMP, informasi tentang subjek yang akan diteliti, serta permasalahan yang dihadapi dalam proses pembelajaran yang telah berlangsung, kemudian melakukan analisis kebutuhan. Selanjutnya tim lesson study membuat desain model pembelajaran yang akan dikembangkan meliputi penentuan tema pembelajaran, penentuan materi pembelajaran, penyusunan silabus, RPP dan perangkat evaluasi. Do, tim lesson study mengembangkan perangkat pembelajaran dengan mengujicobakan produk yang telah dibuat ke Peserta didik. Pada pelaksanaan lesson study menggunakan 3 sampai 5 anggota tim. Salah satu anggota tim bertindak sebagai guru model dan anggota lainnya mengamati proses pembelajaran. See, setelah pelaksanaan pembelajaran, tim lesson study melakukan 
diskusi untuk merefleksi proses pembelajaran. Hasil refleksi digunakan untuk memperbaiki desain model pembelajaran dan dilanjutkan dengan tahapan berikutnya sehingga didapatkan desain model pembelajaran yang sempurna dan siap untuk diimplentasikan.

Selain itu juga akan digali informasi terkait manfaat yang dirasakan guru/calonguru terhadap lesson study. Penelitian ini bertempat di SMP Negeri 3 Ketapang.

Penelitian ini akan dilaksanakan pada semester Ganjil Tahun Pelajaran 2020/2021 dengan memilih guru di SMP Negeri 3 ketapang sebagai responden.

Dengan pelaksanaan Pengembangan Media Pembelajaran Ipa Terpadu Berbasis Komputer Pada Tema Bunyi Melalui Lesson Study dalam proses pembelajaran akan membuka kesempatan seluas luasnya kepada peserta didik untuk ikut aktif dalam pembelajaran. Dengan demikian guru bertanggung jawab penuh dalam memantau peserta didik dalam proses belajar mengajar, maka indicator keberhasilan adalah $85 \%$ peserta didik telah mencapai kriteria ketuntasan minimal (KKM) yaitu 75 sesuai dnegan yang ditetapkan SMP Negeri 3 Ketapang.

\section{HASIL DAN PEMBAHASAN PENELITIAN}

Penelitian diharapkan akan memperoleh hasil sesuai dengan tujuan yang diharapkan. Tujuan penelitian ini adalah untuk mengetahui kelayakan dan keefektifan pengembangan produk media pembelajaran pada tema bunyi. Peneliti melakukan uji coba skala terbatas pada 15 anak kelas IX di SMP Negeri 3 Ketapang dengan pertimbangan bahwa peserta didik kelas IX pernah menerima materi tentang bunyi dan sistem pendengaran. Materi bunyi ini di berikan di kelas VIII semester genap dan materi sistem pendengaran diberikan kelas IX semester ganjil. Alasan lain uji coba diberikan pada kelas IX adalah agar peserta didik memiliki pemikiran yang lebih untuk memberikan saran yang lebih terperinci karena pernah menerima materi tersebut di bandingkan dengan peserta didik kelas VIII yang belum pernah menerima materi tersebut, sehingga diharapkan dapat memberikan saran untuk dapat dijadikan bahan pertimbangan untuk memperbaiki produk media pembelajaran agar media pembelajaran lebih baik.

Hasil tanggapan yang diberikan kepada peserta didik pada uji coba skala terbatas ini, ratarata peserta didik memberikan tanggapan "baik" terhadap media pembelajaran. Dari 15 peserta didik 5 responden yang memberikan tanggapan "sangat baik" 9 responden memberikan tanggapan "baik" dan hanya 1 yang memberikan tanggapan "kurang baik" dan tidak ada peserta didik yang memberikan tanggapan "tidak baik". Peserta didik yang memberikan tanggapan "kurang baik" disebabkan karena perlunya penambahan animasi dalam media pembelajaran. Dengan hasil persentase mencapai $93 \%$ peserta didik memberi tanggapan "sangat baik" dan "baik" menunjukkan bahwa media pembelajaran dinyatakan layak dan dapat diterima oleh peserta didik untuk membantu pemahaman dalam belajar karena hasil tanggapan menunjukkan skor yang menyatakan keberterimaan media pembelajaran karena telah melebihi indicator yang ditentukan.
Berdasarkan hasil angket, beberapa peserta didik memberi masukan dan kritik yang selanjutnya menjadi bahan untuk melakukan revisi produk. Dari peserta didik yang memberi masukan, semuanya memberi masukan untuk menambah gambar atau animasi agar lebih menarik. Banyak pula peserta didik yang menyatakan sudah puas dengan informasi yang diberikan dan materi dalam media pembelajaran mudah dipahami. kemampuan guru untuk menciptakan pembelajaran yang ilmiah dan peserta didik mampu memahami materi dengan baik. Dalam penelitian ini, lesson study digunakan untuk menilai produk media pembelajaran karena dalam penelitian ini produk media pembelajaran yang dikembangkan.

Kegiatan lesson study merupakan salah satu model pelatihan keprofesionalan guru. Kegiatan ini melibatkan beberapa guru IPA sebagai tim ahli. Kegiatan lesson study ini hanya dilaksanakan pada uji coba skala luas. Karena pada uji coba skala terbatas lebih menekankan untuk mengetahui kelayakan media pembelajaran sebelum di uji cobakan pada tahap uji coba skala luas.

Kegiatan lesson study diawali dengan memberikan penjelasan atau workshop terhadap guru yang akan menjadi tim ahli lesson study. Workshop ini bertujuan untuk mengenalkan “apa?", "mengapa?" dan "bagaimana?" lesson study dilaksanakan. Tim lesson study yang terdiri atas guru model dan tim ahli yang berasal dari guru bekerja bersama- sama melaksanakan tahapantahapan dalam lesson study (Rahayu, 2012). Lesson study yang dilaksanakan oleh guru dan tim ahli sangat membantu guru peneliti dalam meningkatkan Rencana Pelaksanaan Pembelajaran. Kegiatan lesson study melibatkan guru dan sekolah, melaksanakan kegiatan secara kolaboratif untuk mengamati proses pendidikan yang dilakukan dengan mempelajarainya untuk mendapatkan solusi dan masukan demi perbaikan proses pembelajaran berikutnya (Santyasa, 2009).

Setelah pembelajaran di kelas selesai, tim lesson study mengadakan pertemuan untuk memberikan refleksi berupa masukan dari proses pembelajaran yang dilakukan oleh guru model. Refleksi-refleksi tersebut natinya digunakan untuk memperbaiki proses pembelajaran tentang hal yang perlu dilakukan oleh guru model di kelas dan hal yang tidak perlu dilakukan oleh guru model di kelas (Winarsih, 2012). Adanya tahap refleksi ini maka proses pembelajaran akan semakin baik, pembelajaran yang semakin baik akan mendukung kemampuan guru untuk menciptakan pembelajaran yang ilmiah dan peserta didik mampu memahami materi dengan baik. Dalam penelitian ini, lesson study digunakan untuk menilai produk media pembelajaran karena dalam penelitian ini produk media pembelajaran yang dikembangkan.

Kegiatan pembelajaran. Kegiatan lesson study pertama yang dilaksnakan pada mata pelajaran IPA Terpadu pada satu kelas peserta didik kelas VIII G Negeri 3 Ketapang. Pada uji coba skala luas ini $100 \%$ peserta didik memberikan tanggapan "sangat baik" dan "baik" sehingga menunjukkan respon baik yang diberikan peserta didik untuk media pembelajaran. Presentase ini menunjukkan peningkatan tanggapan apabila dibandingkan dengan presentase pada tahap uji coba pada kelas IX yang hanya mendapatkan skor sebesar $93 \%$. Hal ini dikarenakan pada peserta didik kelas VIII 
belum pernah memperoleh pembelajaran dengan bantuan media pembelajaran, sehingga ketika pembelajaran dengan media pembelajaran berbasis komputer diberikan, peserta didik merasa senang dan antusias dalam mengikuti pembelajaran.

Rata-rata skor butir tanggapan peserta didik pada saat uji coba skala luas menunjukkan dari sepuluh butir tanggapan peserta didik diperoleh skor $\geq 2,51$ dengan kriterian "sangat baik". Hal ini sesuai dengan keberterimaan media pembelajaran, namun untuk tanggapan peserta didik pada butir 2 mengenai, kesesuaian isi media pembelajaran dengan tujuan pembelajaran mendapat skor 3 dengan kriteria "baik". Hal ini dikarenakan peserta didik kurang memahami tujuan pembelajaran walaupun sudah peneliti tampilkan pada media pembelajaran dan sudah peneliti jelaskan.

Perbandingan rata-rata skor pada uji coba skala terbatas dan skala luas, untuk tanggapan pada butir 3 dan butir 8 mengenai kemudahan untuk mengoperasikan media pembelajaran dan kemandirian penggunaan media pembelajaran, pada uji coba skala terbatas mendapat skor 2,93 dan 2,86 dengan kriteria "baik", namun pada uji coba skala luas mendapat skor 3,28 dan 3,39 dengan kriteria "sangat baik". Hal ini dikarenakan kurangnya pemahaman peserta didik tentang petunjuk media pembelajaran. Pada uji coba skala luas, selain petunjuk pada media pembelajaran, peneliti memberi petunjuk dalam bentuk print out supaya ketika peserta didik kesulitan dalam penggunaan media pembelajaran, peserta didik dapat membaca petunjuk yang telah disediakan oleh peneliti. Perbandingan rata-rata skor yang selanjutnya pada butir tanggapan ke 5, 7, 9 dan 10 mengenai bentuk animasi, motivasi belajar dengan bantuan media pembelajaran, keefektifan pembelajaran dan ketertarikan untuk menggunakan media pembelajaran dalam proses belajar mengajar sehari-hari pada uji coba skala terbatas mendapat tanggapan "baik" tetapi pada uji coba skala luas mendapat tanggapan "sangat baik".

Hal ini terlihat, peserta didik kelas VIII lebih antusias atau lebih tertarik dalam mengikuti proses belajar mengajar dengan bantuan media pembelajaran karena media pembelajaran ini tergolong baru dan pada proses belajar mengajar belum pernah menggunakan media pembelajaran selain itu dalam pembelajaran ini peserta didik diajak untuk mengoperasikan sendiri media pembelajaran selain itu pembelajaran dilakukan dilaboratorium computer sehingga peserta didik tidak merasa bosan.

Selain dari tanggapan peserta didik, tingkat keberterimaan media pembelajaranjuga diukur dari tanggapan guru. Guru memberi tanggapan "baik" terhadap media pembelajaran. Ketujuh butir tanggapan guru, hanya 4 butir yang menunjukkan kriteria "sangat baik" dan 3 butir yang menunjukkan kriteria "baik" yaitu pada butir 2, 4 dan 7. Hal ini dikarenakan pada media pembelajaran yang dikembangkan kurang adanya narasi/ bunyi sesuai dengan tema yang ada, yang ada hanya instrumentalia. Pada butir 4 mendapat kriteria "baik" karena menurut para guru, penggunaan media pembelajaran hanya dapat dilakukan pada materimateri tertentu. Butir ke 7 juga mendapat kriteria "baik" hal ini dikarenakan penyajian materi kurang sesuai dengan peneliti tulis pada RPP.
Walaupun demikian, media pembelajaran sudah dapat dikatakan layak dan baik untuk membantu dalam proses belajar mengajar, karena sudah melebihi kriteria keberterimaan media pembelajaran yaitu $\geq 2,51$. Keseluruhan rata-rata butir tanggapan guru adalah 3,19 dengan kriteria "baik" dan rata-rata skor tanggapan guru adalah 3,14 dengan kriteria "baik". Penggunaan media pembelajaran sangat membantu peserta didik untuk memahami materi yang diajarkan, karena dengan media pembelajaran peserta didik dapat melakukan pengamatan terhadap materi yang bersifat abstrak walaupun hanya dengan melihat gambar. Peserta didik menjadi tidak bosan mengikuti pembelajaran karena selain pembelajaran dilakukan di laboratorium komputer, peserta didik juga dapat melihat gambar dan melakukan pengoperasian sendiri

Hasil evaluasi pada akhir pembelajaran di media pembelajaran dan ulangan harian yang dilaksanakan dapat digunakan sebagai data pendukung untuk mengetahui keefektifan penerapan media dalam pembelajaran. Media pembelajaran dikatakan efektif apabila $\geq 75 \%$ peserta didik mencapai nilai $\geq 75$. Berdasarkan hasil analisis data dari 36 peserta didik yang mengikuti kegiatan belajar, hanya 4 peserta didik yang dinyatakan tidak tuntas dalam hasil belajarnya atau memperoleh nilai kurang dari 75 . Hal ini dikarenakan peserta didik tidak belajar pada saat akan ulangan harian, padahal soal yang peneliti buat sudah sesuai dengan tujuan pembelajaran dan indikator yang harus dicapai. Selain itu, nilai-nilai tambahan yang berasal dari evaluasi 1 dan 2 yang dilaksanakan pada setiap pertemuan mendapat nilai rendah sehingga tidak dapat membantu nilai ulangan harian yang juga rendah. Sebanyak 32 peserta didik dinyatakan memperoleh nilai $\geq 75$ sehingga ketuntasan klasikal telah tercapai, dimana ketuntasan klasikal diperoleh 88,89\%. Ketercapaian ketuntasan klasikal tersebut dikarenakan media pembelajaran telah di validasi oleh validator dengan validitas konstruk, supaya soal yang digunakan baik secara keberterimaan dan keefektifan.

\section{SIMPULAN DAN SARAN}

\section{Simpulan}

Berdasarkan hasil penelitian dapat disimpulkan bahwa: (1) Media pembelajaran IPA terpadu yang dikembangkan layak digunakan sebagai media pembelajaran berbasis komputer untuk tema bunyi dengan keberterimaan $\geq 2,01$ untuk pakar dan $\geq 2,51$ untuk peserta didik dan guru. (2) Media pembelajaran IPA terpadu yang dikembangkan efektif diterapkan digunakan sebagai media pembelajaran berbasis omputer pada tema bunyi untuk kelas VIII dengan pencapaian $\mathrm{KKM} \geq 75$ dengan ketuntasan klasikal $88,89 \%$.

\section{Saran}

Dari hasil penelitian yang diperoleh dari uraian sebelumnya agar pengembangan pembaelajaran dapat meningkat, lebih efektif dan lebih memberikan hasil yang optimal bagi kegiatan pembelajaran sekolah, maka disampaikan saran bagi peneliti yang ingin melanjutkan penelitian ini. 
Adapun saran yang diberikan yaitu sebagai berikut: 1 . Sebaiknya responden yang digunakan dalam penelitian harus sudah mempelajari materi yang akan diuji cobakan; (2) materi yang digunakan sebaiknya dilengkapai dengan animasi atau gambar agar dapat menarik perhatian siswa; (3) penyajian materi sebaiknya sesuai dengan rpp yang digunakan

\section{DAFTAR RUJUKAN}

Arends, R. 1997. Classroom Instructional Management. New York: The Mc GrawHill Company.

Asyhar, R. 2012. Kreatif Mengembangkan Media Pembelajaran. Jakarta:Penerbit Referensi.

Depdikbud. 2012. Metode Tematik Integtarif Bukan Hal Baru. On Line at http://www.kemdiknas.go.id/kemdikbud/berita 1985. [diakses tanggal 21 Januari 2012]

Hadisubroto, dan L. Herawati S. 2000.Pengembangan Terpadu: Materi Pokok PGSD. Jakarta: Universitas Terbuka.

Hendon, ST. Abdullah, S. Khalijah. 2007. Science
Teaching For Enlightenment: A Holistic Approach in developing a Teacher's Guide for best Practices to Teach at Secondary Level, Asia-Pacific Forum on Science Learning and Teaching, 8, Issue 1, Article 12 (June 2007). OnLine at http://www.ied.edu.hk/apfsit/V8_issue1/Hendo nindex.htm\& prev:1 [diakses tanggal 4 Juni 2013]

Hernawan, Resmini \& Andayani. 2008. Pembelajaran Terpadu di SD. Jakarta: Universitas Terbuka.

Indrawati. 2009. Model Pembelajaran Terpadu Di Sekolah Dasar untuk Guru SD. Jakarta: PPPPTK IPA. ied.edu.hk/apfsit/V8_issue1/Hendonindex.htm $\&$ prev:1 [diakses tanggal 4 Juni 2013]

Hernawan, Resmini \& Andayani. 2008. Pembelajaran Terpadu di SD. Jakarta: Universitas Terbuka.

Indrawati. 2009. Model Pembelajaran Terpadu Di Sekolah Dasar untuk Guru SD. Jakarta: PPPPTK 